\title{
MINING RISK-RELATED SENTIMENT IN CORPORATE ANNUAL REPORTS AND ITS EFFECT ON FINANCIAL PERFORMANCE
}

\author{
Renáta MYŠKOVÁ ${ }^{*}$, Petr HÁJEK ${ }^{2}$ \\ ${ }^{1}$ Institute of Business Economics and Management, Faculty of Economics and Administration, \\ University of Pardubice, Studentská 84, 53210 Pardubice, Czech Republic \\ ${ }^{2}$ Institute of System Engineering and Informatics, Faculty of Economics and Administration, \\ University of Pardubice, Studentská 84, 53210 Pardubice, Czech Republic
}

Received 10 July 2020; accepted 23 August 2020

\begin{abstract}
Models that predict corporate financial risk are important early-warning systems for corporate stakeholders. Most models to date have been developed using financial indicators. However, in financial decision-making, increasing attention is being paid to the role of textual information, which may provide additional insight into managerial opinions and intentions and which has recently been used to more effectively predict corporate financial performance. Previous approaches in this regard have predominantly focused on sentiment analysis of managerial communication. However, the role of context-related sentiment remains poorly understood in the financial risk domain. Here, we investigate how risk-related sentiment in verbal managerial communication might predict corporate financial performance, including indebtedness, profitability, market value and bankruptcy risk. To ensure deductive content validity, we propose specific word lists for each type of corporate financial risk and assign each word with positive / negative labels. Our findings provide evidence for a major role of risk-related sentiment as an indicator of corporate performance in terms of financial risks. Notably, using novel risk-related word lists in regression models, we show that a proactive and opportunity-seeking risk management has a significantly positive impact on financial performance, implying that stakeholders should carefully consider the risk-related managerial communication in corporate annual reports.
\end{abstract}

Keywords: sentiment, financial risk, annual report, managerial communication, financial performance.

JEL Classification: G32, M21.

\section{Introduction}

Models to predict corporate financial risk are increasingly important support for decision making by firms' stakeholders, such as investors, financial institutions and regulators. Substantial losses suffered by these stakeholders during the global financial crisis nearly ten years ago and the need to reduce information asymmetry between corporate management

${ }^{\star}$ Corresponding author. E-mail: renata.myskova@upce.cz 
and other firm stakeholders give such prediction models paramount importance in current financial systems. In fact, financial risk affects most decisions made by financial managers to some extent. Financial risk can be defined as uncertainties associated with any form of financing, including market risk, liquidity risk, leverage risk, credit risk and operational risk (Peng et al., 2011). Information obtained from financial markets and financial statements provide important support for managing financial risk and decreasing a firm's exposure to such risk. However, it is generally accepted that this information is insufficient to provide accurate early-warning signs of financial risks (Pröllochs \& Feuerriegel, 2020). In fact, most firm-related information pertaining to financial risk comes in linguistic rather than numerical form (Li et al., 2020). For example, corporate annual reports offer detailed linguistic communication of the risks firms face. In these reports, management discusses the most important risks that apply to the firm, including how the firm plans to handle those risks. Similarly, additional information may be found in other firm releases, such as earnings press releases and conference calls. In particular, uncertainty expressed in this managerial communication seems to be an important indicator of corporate financial risk (Loughran \& McDonald, 2016).

It has been demonstrated that uncertainty in economic news significantly affects consumers' individual perceptions and preferences (van Dalen et al., 2017), an effect with profound theoretical background in the theory of uncertain information and prospect theory (Kahneman \& Tversky, 2013). These theories emphasise that a firm's stakeholders process information asymmetrically, suggesting that emotional information may outweigh positive information communicated by management. Based on these considerations, we argue that emotions in verbal managerial communication indicate corporate financial risk. However, although the past decade has seen increasingly rapid advances in the field of textual analysis in finance (Kumar \& Ravi, 2016; Tsai \& Wang, 2017; Myskova \& Hajek, 2018; Marty et al., 2020), researchers have primarily focused on positive and negative sentiment, and not on risk-related sentiment in firm-related communication. Moreover, verbal communication has rarely been integrated into financial prediction models. To fill this gap in the literature, our broad objective is to explore the consequences of using information regarding corporate risk in verbal managerial communication to predict corporate financial risks. The proposed models aim to provide decision-making support to firms' stakeholders. By enabling them to recognise early warning signs of financial risks, these models can help stakeholders match their relative risk with their own risk tolerance when making financial decisions. We show here that positive perception of risks (proactive and opportunity-seeking risk management) indicates improvement in corporate financial performance in terms of indebtedness, profitability, market value and bankruptcy risk. In summary, this study contributes to the existing literature in the following ways:

- Developing novel risk-related word lists categorised into positive and negative sentiment polarities. The uniqueness of the developed word lists is shown compared with existing finance-specific and general word lists.

- Validating the calculated risk-related sentiment on several prediction tasks within the corporate financial risk domain. This is the first study using sentiment in a risk management context to predict corporate financial performance. 
The remainder of this study is organised as follows. Section 1 overviews related literature on the use of managerial communication in financial decision-making, including the prediction of financial risks. Section 2 formulates the problem being addressed and poses hypotheses to test. Section 3 presents the word lists proposed for risk management and the data used for experimental analysis. Section 4 shows the experimental results and compares the proposed word lists with existing sentiment dictionaries. In last section, the results are discussed and future research directions are outlined.

\section{Related literature}

Analysis of managerial communication has gained significant attention in solving problems of financial decision-making due to the large amounts of textual and audio data containing managerial comments. Previous studies have shown that automated analysis of these data leads to more accurate financial predictions, including predicting abnormal stock returns (Loughran \& McDonald, 2011; Hajek, 2018), financial statement fraud (Goel \& Uzuner, 2016; Hajek \& Henriques, 2017) or corporate bankruptcy (Cecchini et al., 2010; Hajek et al., 2014). Recent surveys of related studies may be found in Kumar and Ravi (2016) or Loughran and McDonald (2016). It is therefore becoming increasingly difficult to ignore the contribution that verbal managerial communication may make to financial prediction. For example, communication has been shown to carry complementary, qualitative information about the firm's current and future prospects that is reflected in the expectations of firms' stakeholders. This also applies to corporate financial risk (Loughran \& McDonald, 2011). In addition, as reported in Yang et al. (2018), audit fees are significantly and positively related to firm-specific financial risks, indicating the informativeness of textual corporate risk disclosures.

A wide range of prediction models have recently been proposed for the early detection of corporate financial risk. However, the identification and potential effects of risk events on corporate financial performance have not been dealt with. This is attributed to the complexity of this task (Salameh \& Bashir, 2013; Bunget et al., 2014), which arises from the fact that business sustainability is assessed not only in terms of efficient use of resources and procedures (operational efficiency is reflected in corporate financial performance, see Marc et al., 2018) and in the growth of share value (Guenster et al., 2011; Cai \& He, 2014), but also that the firm's performance is also assessed in relation to the quality of business environment (Džunić \& Golubović, 2018), often with positive impacts of CSR (Manzoor et al., 2019) and environmental protection practices (Flammer, 2013; Fuente et al., 2016; Chen et al., 2017; Kumar et al., 2017; Myskova \& Hajek, 2018).

Here, we briefly review the literature related to the prediction of corporate financial risk using verbal and nonverbal communication of firm-related data. For the purpose of this project, corporate financial risk includes the following: (1) market risk, (2) liquidity and leverage risk, (3) credit risk, and (4) operational risk.

Market risk includes risks common to all companies in a market or industry - such as currency, interest rate and commodity risks - as well as those risks specific to each firm's market position, usually represented by volatility risks. Several studies have recently demonstrated that the textual analysis of news and managerial communication may improve the 
accuracy of volatility prediction models (Loughran \& McDonald, 2011). However, research to date has tended to focus only on the sentiment analysis of documents (Groth \& Muntermann, 2011; Tsai \& Wang, 2017). To summarise the findings of these studies, high levels of sentiment (positive or negative) increase stock return volatility over both the short and long term. For example, according to Huang et al. (2014), the announcement of positive economic results in corporate press releases has been followed by sharply increased returns on the stock market. Increases in the market value and share price are also associated with positive information about the firm's competitiveness in the market (Smalt \& McComb, 2016). Similarly, DellaVigna and Pollet (2009) mentioned the need for corporate press releases to reduce investors' asymmetry of information.

In contrast to market risk, surprisingly little attention has been paid to the prediction of liquidity or leverage risk in the literature. Notably, Bodnaruk et al. (2015) found that negative sentiment of managerial communication in corporate annual reports can be used to accurately predict subsequent liquidity events expressed in terms of dividend cuts or omissions, debt downgrades and asset growth. They reported that such predictions are more effective than traditional financial indicators of liquidity risk.

Regarding credit risk, several important findings have recently been reported. First, textual information from news and managerial comments contains incremental informational content for evaluating firms' credit risk (Smales, 2016; Tsai et al., 2016). Second, a higher volume of risk-factor disclosures indicates higher credit risk (Tsai et al., 2016; Deaconu et al., 2016). Finally, user-generated social media content can enhance the information base for analysing corporate credit risk (Mengelkamp et al., 2015).

Operational risk is often associated with firms' activities aimed at creating and developing unique assets. The fact that the market value of firms is much higher than their book value may be due to some assets not being included in the balance sheet, even though they play a major role in generating corporate wealth. This has been confirmed by several empirical studies showing that the current accounting concept of intangible assets does not reflect the actual state and implicitly distorts the firm value (Salameh \& Bashir, 2013; Greco et al., 2013; Chen et al., 2016; Clausen \& Hirth, 2016; Bužinskienè, 2017; Osinski et al., 2017; Fejes, 2018). Moreover, this approach has several drawbacks that, without additional commentary, reduce the relevance of the financial statements (Jordao \& Almeida, 2017). Cosmulese et al. (2019) refer to the need to explain how an accounting entity, as an organised system, purchases inputs, transforms them and converts them into market outputs with an added value.

Arora and Lodhia (2016) and Eidelwein et al. (2018) link the reduction in operational risks (specifically, business risks, employee risks and litigation risks) with the implementation and presentation of correct behaviour in the field of environmental protection. According to Walls et al. (2012) and Liu and Zhang (2016), such behaviour also reduces the reputation risk and promotes the reputation of the firm. This is why a number of previous studies recommend including environmental information in financial reports (Cormier \& Magnan, 2015; Clarkson et al., 2013; Song et al., 2017).

Thus far, however, the literature related to operational risks has been mainly focused on the risks of financial fraud (i.e., financial losses resulting from deception). Indeed, intentional misrepresentation in the content of managerial comments may indicate fraudulent misrep- 
resentation of financial statements (Gray \& Debreceny, 2014). In fact, most major financial fraud has involved members of senior management, who have the opportunity, ability and incentive to commit fraud (Hajek \& Henriques, 2017). The empirical evidence suggests that negative, uncertain and litigious linguistic attributes are all significantly linked to future lawsuits concerning financial fraud (Loughran \& McDonald, 2011). Moreover, both positive and negative sentiment seem to be more pronounced in fraudulent reports.

Although a growing body of literature has studied the role of managerial communication in financial decision-making, several important issues must still be addressed. First, as noted above, the effects of verbal managerial communication related to corporate risks have not been examined for predicting corporate financial performance, which is surprising as risk-related information is assumed to provide a more focused view of the managerial perspective. Second, previous studies have concentrated on sentiment analysis of managerial communication, but uncertainty or other risk-related emotions in managerial communication may also indicate corporate financial risk. Third, previous studies have not accounted for the context of corporate financial risk. More precisely, they did not differentiate between the topics of managerial comments. For example, managerial communication in annual reports was analysed as a whole, rather than focusing on those sections related to corporate risks. This paper aims to fill these gaps in the literature.

\section{Problem formulation and hypotheses}

The aim of this study is to assess the consequences of using information on corporate risks hidden in managerial communication with stakeholders. To achieve this aim, we develop a novel dictionary for mining risk-related sentiment. At the same time, we apply several existing dictionaries from the business and financial domains to evaluate how the risk communication and quality of risk management are related to a company's value and economic results. The texts of the annual reports of selected companies monitored the extent to which attention is paid to risks, their detection, perception and impact, including risk management practices, in connection with selected financial indicators.

When developing our dictionary, it was necessary to respect the definition of risk in the literature, thus reflecting two fundamental approaches: (1) risk is considered only as a threat (Haimes, 2009), consisting of the risk of negative deviations from the stated objectives; and (2) risk is considered a possible opportunity when the opportunity can be accepted, shared, strengthened or used (Kerzner, 2009).

At the same time, it was taken into account that the breakdown of risks is based not only on certain common aspects, but also on contradictions. Inter alia, it includes these (already mentioned above) risks: (a) tangible and intangible; (b) controllable and uncontrollable; (c) insurable and uninsurable; (d) systemic and non-systemic; and (e) strategic, tactical and operational (when considering the level of decision-making). Although all risks in companies are ultimately assessed in monetary units, risk categorisation distinguishes between financial and non-financial risks. Therefore, the dictionary should contain an even more detailed categorisation - for example, in the group of non-financial risks there are technical, personnel and political risks. 
It is also important to accept the division of risks in terms of the relationship to the entity that is the bearer of the risk, i.e., the distinction between external and internal risks. External risks cannot usually be controlled or managed - for example, macroeconomic risks. Internal risks relate to factors within the company and are controllable, e.g., operational, financial, supplier, organisational or security risks. Some types of risks can be understood as both external and internal, such as environmental risks or risks associated with information security. Another division focuses on simple, complex, uncertain and ambiguous risks. Furthermore, the dictionary should include terms related to the impact of risk, its treatment and control and methods for risk management. Finally, to obtain the risk-related sentiment, each term must be assigned a positive or negative polarity according to its impact on society.

To examine the validity of the above assumption about the role of risk-related sentiment in annual reports, the following hypotheses were formulated.

Financially weak companies tend to hold more cash than those with a strong capital position (López-Gracia \& Sogorb-Mira, 2015; Chang et al., 2017). Therefore, some companies seek to maintain higher liquidity as an important asset for financing investments without increasing external resources (Anton \& Nucu, 2019), thus creating a stable impression for stakeholders (Tong, 2014) - this is reflected in the formulation of corporate financial policies (Maheshwari \& Rao, 2017). Insufficient capital, which cause high indebtedness, endangers companies not only in terms of rising costs associated with interest on external capital but also increased concerns of creditors associated with late payment or even uncollectible receivables. Therefore, it can be assumed that management is motivated to explain the reasons for higher indebtedness and will promote its reputation by analysing and responsibly describing risks.

Hypothesis 1a (H1a). Companies with higher indebtedness pay more attention to risks in their annual reports.

Concerning net assets, a higher value indicates an economically stronger company. In connection with risk awareness, high net assets psychologically give the impression of a solid, trustworthy and stable company whose management behaves responsibly towards society and the environment. The approach to risks in these cases is usually associated with a positive conception of risk because management presents itself as proactive, seeking opportunities and less focused on the mere elimination of threats. Indebtedness was also found to be negatively correlated with positive sentiment calculated using the dictionary of Loughran and McDonald (2011). Therefore, if management describes the risks more positively, it can be assumed that the company's indebtedness will decrease.

Hypothesis $\mathbf{1 b}(\mathbf{H} \mathbf{1 b})$. With the growth of positive perception of risks in companies, indebtedness decreases.

Good risk analysis allows companies to better manage risks, either in the form of risk transfer, risk retention or risk reduction. Consistent risk management due to the elimination of damage costs - e.g., in the form of risk prevention - leads to improved economic results. According to Stulz (2013), the management of most companies has a limited capacity to bear risk, meaning that even risk management strategies cannot succeed without effective commu- 
nication (Tsai \& Wang, 2017). We therefore assume that companies with higher profitability not only have more information about risks but also communicate that information more with stakeholders. The most striking finding of Myskova and Hajek (2017) suggests that annual reports with high frequencies of words related to profitability and leverage are positively correlated with ROA and debt ratio. The ROA indicator of profitability was also used in this study because it is considered more accurate and less influenced by creative accounting than the ROE indicator (Vojinović et al., 2020).

Hypothesis 2a (H2a). Companies with higher profitability (ROA) pay more attention to risks in their annual reports.

The readiness to manage risk is also associated with the ability to look at risk as an opportunity, not just as a threat. In other words, a proactive and positive approach to risk management can be assumed to indicate an increase in profitability. This also conforms with previous evidence observed for positive and negative sentiment categories (Myskova \& Hajek, 2017). Generally, companies with good financial performance are not only expected to verbally comment on the achieved performance but also to elaborate on any positive or negative effects on the company. Conversely, poorly performing companies are reportedly concise in their managerial discussions, only describing the causes of the poor results.

Hypothesis $\mathbf{2 b}$ (H2b). Profitability increases with the growth of positive perception of risks in companies.

Assuming that early identification of risks leads to their elimination, Hypothesis H3a was expressed in order to consider overall financial performance and bankruptcy risk. Altman's bankruptcy model, the so-called Z-score (Altman, 1968; Altman et al., 2017), was chosen to confirm because it is considered sufficient for American companies to determine the probability that a company will go bankrupt in the medium term (Sulub, 2014; Kubenka \& Myskova, 2019). Finance-specific sentiment dictionaries proved to be important indicators of future financial distress (Hajek et al., 2014). Hypothesis H3b again assumes an active approach to risk management and the search for opportunities.

Hypothesis 3a (H3a). Stable companies that are not at risk of bankruptcy pay more attention to risks in their annual reports.

Hypothesis $\mathbf{3 b} \mathbf{( H 3 b ) . ~ B a n k r u p t c y ~ r i s k ~ d e c r e a s e s ~ w i t h ~ t h e ~ g r o w t h ~ o f ~ p o s i t i v e ~ p e r c e p t i o n ~ o f ~}$ risks in companies.

Stock market indicators, unlike profitability indicators, analyse a company's economic situation from the perspective of existing and potential investors by assessing the market and book value of the company (Sejkora \& Duspiva, 2015). A higher ratio of market to book value, which gives the company the appearance of being stable and prosperous, leads to increased interest from investors. Usually, the growth of the market value is associated with a higher dividend yield, which denotes the return on the investment, thus actually motivating investors to hold or buy the company's shares. It is important to assess the dividend yield not only as such, but also against the market value because if this indicator increases only due to a decline in the market price, then the sale of the share decreases. 
We assume that corporate management considers sufficient investor information to be a positive psychological aspect because managerial comments presented in annual reports and other company-related documents allow stakeholders to better assess the current and future value of the company (Kearney \& Liu, 2014). This assumption is supported by empirical evidence provided for the positive and negative finance-specific word lists (Myskova \& Hajek, 2017).

Hypothesis $4 \mathbf{a}$ (H4a). With the growth of attention to risks in a company's annual reports, market to book value decreases.

Hypothesis $\mathbf{4 b}$ (H4b). Market to book ratio increases with the growth of risk-related positive sentiment.

\section{Research methodology and data}

Since we focused the modelling of emotions in managerial communication on the domain of corporate financial risk, we created specific word lists for each type of corporate financial risk, considering both single words and word phrases. To develop the risk-related word lists, we adopted the approach used in earlier research (Short et al., 2010; Myskova \& Hajek, 2018). To develop an initial list of words, we used the dictionary of financial risk management (Gastineau \& Kritzman, 1999). In the next step, we searched for the words in the WordNet ontology to include their domain synonyms. Lastly, three experts in financial risk management were asked to review the list of words and to assign each word with positive / negative labels. Thus, deductive content validity was ensured and we were enabled to calculate the risk-related sentiment. Note that majority vote was applied in case of an ambiguous decision of the group of experts. The word lists are given in Appendix (A: positive risk-related word list and B: negative risk-related word list). Specifically, we calculated the counts of positive and negative risk-related words normalised by the length of the annual report and thus obtained positive and negative sentiment, respectively. The overall risk-related net positive (NP) sentiment was obtained as follows (Henry \& Leone, 2016):

$$
\text { risk-related NP sentiment }=\frac{\# \text { positive words }-\# \text { negative words }}{\# \text { positive words }+\# \text { negative words }} \text {. }
$$

Generally, previous literature has prioritised general linguistic sentiment as the most important managerial communication characteristic (Henry \& Leone, 2016; Loughran \& McDonald, 2016). By contrast, we consider a sentiment indicator specifically designed for the risk management domain. Also note that earlier literature has shown that word lists from other domains, such as the General Inquirer (sociology) or Diction (politics), are inappropriate for the sentiment analysis of financial texts because terms important in the context of financial disclosure are often omitted from these word lists, and negative terms on these lists are often positive in the financial context (Henry \& Leone, 2016). Several domain-specific financial word lists have been proposed to overcome this issue, such as those proposed by Loughran and McDonald (2011). Adopting this rationale, we used the domain-specific word lists from Loughran and McDonald (2011) to represent verbal sentiment in managerial communication and to estimate the level of uncertainty and modality. Finally, the Diction 
word lists were used to complete the range of verbal emotions, including activity/passivity, overstatement/understatement, ambivalence, realism, praise, satisfaction, denial, aggression, excitation, and so on. Again, word counts in these categories were calculated to obtain corresponding linguistic indicators. We opted for Loughran \& McDonald's word lists and the Diction word lists in order to control for finance-specific sentiment and general sentiment, respectively. This enabled us to demonstrate the uniqueness and validity of our word lists.

To obtain the data for experimental evaluation, we collected textual data for the predefined set of U.S. companies listed on two major stock markets: the New York Stock Exchange and NASDAQ. Their annual reports from 2017 (10-K filings) were taken from the U.S. Securities and Exchange Commission's EDGAR System (2019). Overall, we were able to collect the data for 2,935 companies. The predictive capacity of the risk-related sentiment was further examined using the next year's financial performance. Quantitative data for 2018 on indicators of corporate financial risk were collected from the Value Line database, which provides historical data covering income statements, balance sheets, cash flow statements and other data necessary for fundamental corporate analysis. To represent the financial risk indicators, the following indicators were chosen: (1) indebtedness (TD/TA, total debt to total capital); (2) profitability (ROC, return on capital); (3) bankruptcy risk (Z-score calculated as recommended in (Hajek et al., 2014); and (4) market to book value (PBV, price to book value). Mean values of the variables are presented in Table 1.

Following the above studies, the effect of risk-related sentiment in annual reports on financial indicators was examined. To control for other determinants of financial risks, we also considered indicators found significant in previous empirical research. Because financial risks are generally affected by firm size, we included TA (total assets) in our regression models. In addition, ROC is reported to be driven by DY (dividend yield), PR (payout ratio), leverage (TD/E, total debt to equity) and PBV (Fama \& French, 2000). Previous research also suggests that indebtedness increases with TA, PR, DY and PBV and decreases with ROA (Frank \& Goyal, 2009). Also, in agreement with Myskova and Hajek (2016), we considered TA, ROE (return on equity), P/E (price to earnings), PEG (price / earnings-to-growth), PR, DY and TD/E.

For statistical analyses, we used three methods: (1) Pearson correlation coefficients to detect significant correlations between risk-related word counts and financial indicators (Hypotheses 1a, 2a and 4a); (2) Student's paired $t$-test to detect statistical differences between companies in safe and financial distress $\mathrm{Z}$-score categories (Hypotheses $3 a$ and $3 b$ ), and (3) linear regression models to examine the effects of risk-related sentiment on TD/TA, ROA and PBV (Hypotheses 1b, 2b and 4b). For the regression models, we also tested for multicollinearity and heteroscedasticity using variance inflation factors and Levene's tests, respectively. In addition, we calculated the Durbin-Watson statistics and observed no linear auto-correlation in the used variables. All experiments were performed in IBM SPSS Statistics 26.

Table 1. Mean values of the used variables

\begin{tabular}{|l|c|}
\hline \multicolumn{1}{|c|}{ Variable } & Mean value \\
\hline Risk-related words & 0.2185 \\
\hline Risk - NP sentiment & 0.1434 \\
\hline TD/TA & 0.3798 \\
\hline ROA & 0.3635 \\
\hline Z-score & 2.1962 \\
\hline PBV & 3.8613 \\
\hline
\end{tabular}




\section{Experimental results}

In the first run of experiments, we examined the value added of the proposed word lists. Therefore, correlations between the tested word lists were calculated. As can be seen in Table 2, all correlations between the risk-related sentiment and those obtained from Loughran and McDonald (2011) and Diction were below 0.4. These results suggest that the LM (Loughran and McDonald) negative sentiment category is correlated with any risk, regardless of polarity. This also conforms with the negative correlations between risk-related sentiment categories and LM positive sentiment. When considering the Diction word lists, significant correlations were found only for optimism and activity, indicating that a certain proportion of risk-related words sound optimistic and that risk-related words are lacking in the aggression, accomplishment and communication word categories. Overall, the correlations are relatively weak, suggesting a high level of uniqueness of the proposed risk-related sentiment categories and their disagreement with existing finance-specific or general dictionaries.

Further experiments were conducted to confirm or reject the hypotheses posed in the previous section.

The link between indebtedness, the amount of assets and the return on invested capital is one of the fundamental aspects of long-term capital allocation decisions. Indebtedness is considered a typical financial risk because higher indebtedness triggers fixed payments and threatens a company with an increased risk of insolvency. The expectations of owners and investors are compromised in the event of growing indebtedness, and therefore more information is required about the risks that the company may face and about the readiness of management to eliminate them.

Indebtedness may not be a major problem in itself, but it is necessary to monitor the impact of the cost of capital on a company's profitability. As early as 1993, the American economist Ghosh stated in his research conducted in the USA that managers prefer highcost loans to dividend cuts (Ghosh, 1993). In general, owners take a negative view of the

Table 2. Pearson correlation coefficients between risk-related sentiment and other word lists

\begin{tabular}{|l|c|c|c|}
\hline \multicolumn{1}{|c|}{$\begin{array}{c}\text { Compared lexicon } \\
\text { sentiment }\end{array}$} & $\begin{array}{c}\text { Risk - negative } \\
\text { sentiment }\end{array}$ & $\begin{array}{c}\text { Risk - positive } \\
\text { sentiment }\end{array}$ & $\begin{array}{c}\text { Risk - NP } \\
\text { sentiment }\end{array}$ \\
\hline LM - Negative & $0.143^{\star}$ & $0.166^{\star}$ & 0.060 \\
\hline LM - Positive & $-0.278^{\star}$ & $-0.246^{\star}$ & $0.181^{\star}$ \\
\hline LM - NP sentiment & $-0.359^{\star}$ & $-0.351^{\star}$ & $0.129^{\star}$ \\
\hline LM - Uncertainty & -0.045 & -0.056 & -0.076 \\
\hline LM - Litigious & 0.041 & 0.055 & $0.117^{\star}$ \\
\hline LM - Modal & 0.004 & -0.017 & -0.084 \\
\hline Diction - Certainty & -0.053 & -0.015 & $0.263^{\star}$ \\
\hline Diction - Optimism & $0.115^{\star}$ & $0.105^{\star}$ & -0.068 \\
\hline Diction - Realism & 0.039 & 0.002 & $-0.224^{\star}$ \\
\hline Diction - Activity & $-0.281^{\star}$ & $-0.276^{\star}$ & 0.080 \\
\hline Diction - Commonality & -0.051 & -0.037 & 0.075 \\
\hline
\end{tabular}

Note: ${ }^{\star}$ significant correlation at $P=0.05$. 
suspension of payments or declines in dividends, and the results show that this view is still respected by management. At the same time, managerial comments focus on the possible risks associated with the payment of profits.

Overall, Table 3 indicates that Hypothesis H1a was confirmed: companies with higher indebtedness pay more attention to risks. Our results in Table 4 also show that the indebtedness of the companies decreases with a positive approach of management to risks (Hypothesis H1b was confirmed). The management of these companies has a certain tendency to risk and seeks opportunities that represent a higher risk. Higher risks are associated with a significant failure to achieve the planned results (downside risks), but at the same time, if successful, they can bring better economic results than less risky options. At the same time, there is a preference for upside risks when the possibilities of exceeding the planned results are mentioned. It can therefore be stated that companies strive for integrated risk management.

From the point of view of stakeholders, the risk of their investment is associated with systematic risks (risks caused by the country's economy) and unsystematic risks (sector risks, risks of a specific company). The negative acceptance of these risks increases the requirements for return on invested capital. The selected ROA indicator measures the performance (or productive power) of a company independently of the sources from which the company's assets were acquired. The assumption that companies with lower profitability will not be interested in presenting possible risks in order not to increase the pressure of investors to improve the achieved economic results was expressed in the form of Hypothesis H2a. However, Hypothesis H2a (companies with higher profitability pay more attention to risks in their annual reports) cannot be unequivocally confirmed or rejected, as the correlation is not significant.

Table 3. Pearson correlation coefficients between risk sentiment and financial ratios

\begin{tabular}{|l|c|c|c|c|}
\hline \multicolumn{1}{|c|}{ Variable } & $\begin{array}{c}\text { Risk-related } \\
\text { words }\end{array}$ & $\begin{array}{c}\text { Risk - negative } \\
\text { sentiment }\end{array}$ & $\begin{array}{c}\text { Risk - positive } \\
\text { sentiment }\end{array}$ & $\begin{array}{c}\text { Risk - net positive } \\
\text { sentiment }\end{array}$ \\
\hline TD/TA & $0.120^{\star}$ & $0.127^{\star}$ & $0.108^{\star}$ & $-0.127^{\star}$ \\
\hline ROA & $-0.063^{\star}$ & $-0.088^{\star}$ & $0.068^{\star}$ & 0.128 \\
\hline PBV & -0.017 & -0.016 & -0.014 & 0.014 \\
\hline
\end{tabular}

Note: ${ }^{\star}$ significant correlation at $P=0.05$.

Table 4. Effect of risk-related sentiment on TD/TA

\begin{tabular}{|l|c|c|c|c|}
\hline \multicolumn{1}{|c|}{ Variable } & $b^{*}$ & $b$ & $t$-value & $p$-value \\
\hline Intercept & & 0.206 & 2.778 & $0.006^{* * *}$ \\
\hline TA & 0.040 & 0.000 & 1.375 & 0.170 \\
\hline PR & 0.015 & 0.001 & 0.533 & 0.594 \\
\hline DY & 0.167 & 1.408 & 5.663 & $0.000^{* * *}$ \\
\hline PBV & 0.134 & 0.001 & 4.773 & $0.000^{* * *}$ \\
\hline ROA & -0.031 & -0.010 & -1.069 & 0.285 \\
\hline Risk - NP sentiment & -0.070 & -0.367 & -1.989 & $0.047^{* *}$ \\
\hline
\end{tabular}


End of Table 4

\begin{tabular}{|l|c|c|c|c|}
\hline \multicolumn{1}{|c|}{ Variable } & $b^{*}$ & $b$ & $t$-value & $p$-value \\
\hline Risk-related words & 0.034 & 0.000 & 1.046 & 0.296 \\
\hline LM - NP sentiment & -0.141 & -5.677 & -3.082 & $0.002^{* * *}$ \\
\hline LM - Uncertainty & -0.167 & -12.098 & -4.241 & $0.000^{* * *}$ \\
\hline LM - Litigious & 0.040 & 2.479 & 1.201 & 0.230 \\
\hline LM - Modal & -0.045 & -25.235 & -1.510 & 0.131 \\
\hline Diction - Certainty & -0.055 & -1.531 & -1.757 & $0.079^{*}$ \\
\hline Diction - Optimism & -0.014 & -0.653 & -0.456 & 0.648 \\
\hline Diction - Realism & 0.269 & 1.806 & 6.312 & $0.000^{* * *}$ \\
\hline Diction - Activity & 0.068 & 2.180 & 2.006 & $0.045^{* *}$ \\
\hline Diction - Commonality & -0.040 & -1.809 & -1.224 & 0.221 \\
\hline$R^{2}$ & 0.145 & & & \\
\hline$R^{2}-$ Adj. & 0.115 & & & \\
\hline$R^{2}-$ Adj. & 0.246 & & & \\
\hline
\end{tabular}

Notes: ${ }^{* *}$ significant at $P=0.01,{ }^{* *}$ significant at $P=0.05,{ }^{*}$ significant at $P=0.1$, TA - total assets, $\mathrm{PR}$ - payout ratio, DY - dividend yield, PBV - price to book value.

Table 5. Effect of risk-related sentiment on ROA

\begin{tabular}{|l|c|c|c|c|}
\hline \multicolumn{1}{|c|}{ Variable } & $b^{*}$ & $b$ & $t$-value & $p$-value \\
\hline Intercept & & -0.306 & -1.225 & 0.221 \\
\hline TA & -0.022 & -0.000 & -0.718 & 0.473 \\
\hline PR & 0.030 & 0.006 & 1.017 & 0.309 \\
\hline DY & 0.014 & 0.367 & 0.439 & 0.661 \\
\hline PBV & 0.022 & 0.000 & 0.655 & 0.513 \\
\hline TD/E & -0.020 & -0.000 & -0.591 & 0.554 \\
\hline Risk - NP sentiment & 0.074 & 1.240 & 2.006 & $0.045^{* *}$ \\
\hline Risk-related words & -0.053 & -0.000 & -1.561 & 0.119 \\
\hline LM - NP sentiment & 0.126 & 0.778 & 2.869 & $0.004^{* *}$ \\
\hline LM - Uncertainty & 0.022 & 5.091 & 0.531 & 0.595 \\
\hline LM - Litigious & 0.085 & 16.894 & 2.442 & $0.015^{* *}$ \\
\hline LM - Modal & -0.059 & -105.376 & -1.879 & $0.060^{*}$ \\
\hline Diction - Certainty & -0.025 & -2.269 & -0.775 & 0.439 \\
\hline Diction - Optimism & 0.105 & 15.809 & 3.302 & $0.001^{* * *}$ \\
\hline Diction - Realism & -0.085 & -1.829 & -1.904 & $0.057^{*}$ \\
\hline Diction - Activity & -0.057 & -5.872 & -1.609 & 0.108 \\
\hline Diction - Commonality & 0.107 & 15.685 & 3.174 & $0.002^{* * *}$ \\
\hline$R^{2}$ & 0.076 & & & \\
\hline$R^{2}-$ Adj. & 0.060 & & & \\
\hline$R^{2}-$ Adj. & 0.246 & & & \\
\hline
\end{tabular}

Notes: ${ }^{* *}$ significant at $P=0.01,{ }^{* *}$ significant at $P=0.05,{ }^{*}$ significant at $P=0.1$, TA - total assets, $\mathrm{PR}$ - payout ratio, DY - dividend yield, $\mathrm{PBV}$ - price to book value, TD/E - total debt to equity. 
However, we did confirm Hypothesis H2b: profitability increases with the growth of positive perception of risks in companies (Table 5). A more positive presentation of risks does not raise such concerns among investors, investors do not require higher returns and, therefore, there is no increase in the cost of capital. In line with the generally accepted assertion that a minimum average cost of capital, a firm reaches maximum market value, Hypothesis H4a was confirmed. It has been confirmed that the market value decreases with a higher incidence of risk information, which corresponds to the psychological aspects associated with investment decisions and the owners' requirements for the security of their investment (Table 6). Although a positive acceptance of risks increases the likelihood of making better use of changes within companies and in the business environment to achieve better economic results, according to the results obtained, the positive colouring of textual information about risks did not dispel investors' concerns too much; thus, Hypothesis $\mathbf{H} 4 \mathbf{b}$ was rejected.

Our further research focused on the identification of risks in relation to the overall financial performance of companies associated with the prediction of possible bankruptcy (Table 7). Altman's model (Z-score) categorises companies into three zones: safe, grey and financial distress. The model is intended for American companies operating in the industrial sector with shares traded on the public market (note that the original model from 1968 was revised several times, see Altman et al., 2017).

Table 6. Effect of risk-related sentiment on PBV

\begin{tabular}{|l|c|c|c|c|}
\hline \multicolumn{1}{|c|}{ Variable } & $b^{*}$ & $b$ & $t$-value & $p$-value \\
\hline Intercept & & 1.992 & 1.233 & 0.218 \\
\hline TA & 0.004 & 0.000 & 1.562 & 0.119 \\
\hline ROE & 0.054 & 1.586 & 13.602 & $0.000^{\star * *}$ \\
\hline P/E & 0.005 & 0.001 & 0.690 & 0.490 \\
\hline PEG ratio & -0.001 & -0.003 & -0.343 & 0.732 \\
\hline PR & 0.003 & 0.068 & 0.485 & 0.628 \\
\hline DY & -0.011 & -30.493 & -4.561 & $0.000^{* * *}$ \\
\hline TD/E & 0.952 & 1.613 & 240.742 & $0.000^{\star * *}$ \\
\hline Risk-related words & -0.008 & -0.000 & -3.097 & $0.002^{\star * *}$ \\
\hline Risk - NP sentiment & -0.001 & -0.291 & -0.073 & 0.941 \\
\hline LM - NP sentiment & 0.015 & 8.144 & 4.673 & $0.000^{* * *}$ \\
\hline LM - Uncertainty & 0.004 & 86.603 & 1.414 & 0.158 \\
\hline LM - Litigious & 0.001 & 21.970 & 0.482 & 0.630 \\
\hline LM - Modal & -0.003 & -523.410 & -1.519 & 0.129 \\
\hline Diction - Certainty & 0.002 & 12.540 & 0.670 & 0.503 \\
\hline Diction - Optimism & 0.002 & 28.935 & 0.968 & 0.333 \\
\hline Diction - Realism & -0.007 & -13.795 & -2.208 & $0.027^{* *}$ \\
\hline Diction - Activity & -0.003 & -23.085 & -0.973 & 0.331 \\
\hline Diction - Commonality & 0.005 & 59.632 & 1.882 & $0.060^{*}$ \\
\hline$R^{2}$ & 0.258 & & & \\
\hline$R^{2}-$ Adj. & 0.246 & & & \\
\hline
\end{tabular}

Notes: ${ }^{* *}$ significant at $P=0.01,{ }^{* *}$ significant at $P=0.05,{ }^{*}$ significant at $P=0.1$, TA - total assets, ROE - return on equity, P/E price to equity, PEG - price / earnings-to-growth, PR - payout ratio, DY - dividend yield, TD/E - total debt to equity. 
Table 7. Student's paired $t$-test for companies in safe zone vs. financial distress

\begin{tabular}{|l|c|c|c|}
\cline { 2 - 4 } \multicolumn{1}{c|}{} & \multicolumn{3}{c|}{ Z-score category } \\
\hline \multicolumn{1}{c|}{ Risk-related sentiment } & Safe zone & Financial distress & $t$-value \\
\hline Risk-related words & 20546.7 & 24174.1 & $-6.15^{\star}$ \\
\hline Negative & 8784.8 & 10451.4 & $-6.54^{\star}$ \\
\hline Positive & 11761.9 & 13722.7 & $-5.81^{\star}$ \\
\hline Net positive & 0.148 & 0.137 & $5.02^{\star}$ \\
\hline
\end{tabular}

Note: ${ }^{\star}$ significant correlation at $P=0.01$.

The prediction of the future development of a company using one output numerical value is based only on accounting information. The risks caused by the environment (which the management of all companies is aware of, according to our results) are not taken into account, so it was not confirmed that companies in the safe zone discuss risks more than those in the financial distress category. Another reason may be that the management of companies does not know the degree of risk aversion of owners and especially potential investors, so it informs them cautiously. Indeed, Hypothesis H3a was rejected. However, with a positive risk perception, the Z-score value increased; therefore, Hypothesis $\mathbf{H} 3 \mathbf{b}$ was confirmed.

\section{Conclusions}

Combining qualitative (textual) information with quantitative financial data allows the decision-maker to increase the success of future investments or to reduce losses resulting from holding an unsuitable underlying asset. Financial statements cannot be considered as a sufficient information base, mainly because they do not reflect the effects of the environment on economic activities and therefore do not allow a sufficient prediction of the company's further development.

Another important decision is what financial indicators are used for performance evaluation. The authors are aware of the importance of other indicators not mentioned in this article, such as ROE and liquidity indicators, activity and other capital market indicators. ROA was preferred because it helps investors measure how management uses their assets or resources to make more profit, while ROE is often associated with how investments generate income. The profitability of a company is also affected by liquidity, which in the case of high values indicates the freezing of free funds in other forms of current assets. In addition, it is necessary to consider whether the assets are real and whether their amount is undistorted. Similarly, it would be possible to draw attention to the problems associated with the other indicators mentioned above. In connection with the Altman model used in this study, it can also be mentioned that it does not include the issue of high insolvency, which may be a problem of the current economic situation of individual countries.

The psychological expectations of owners and potential investors affected by market developments also play an important role, as most investors prefer a return on their investment 
and a profit in the short term. Keynes already expressed this in the theory of psychological analysis (Fazzari \& Variato, 2015). It follows from the above that the necessary textual information relates to several areas - it combines economic criteria with psychological expectations of stakeholders, managerial approaches to business economics with the ability to communicate with other entities and the way of risk attitude and risk management.

In conclusion, it can be stated that financial decision-making is a multi-criteria problem that places great demands on the quality of managerial communication. Our study provides insight into the role of risk-related managerial communication as an indicator of corporate financial performance. We found that the proposed word lists provide substantial uniqueness to the existing word lists, regardless of their being general or finance specific. Our findings provide strong support for the informativeness of risk-related managerial discussions with stakeholders. The sentiment of this communication seems to be more indicative of financial performance in terms of indebtedness, profitability and bankruptcy risk. More precisely, we found that risk-related sentiment is a more important indicator than just attention given to risk management. This is in agreement with related research on the role of sentiment in managerial communication (Loughran \& McDonald, 2016; Myskova \& Hajek, 2017; Tsai \& Wang, 2017; Pejic Bach et al., 2019). To evaluate corporate financial performance in terms of fundamental analysis, it is therefore recommended to carefully consider the tone of risk management communication carefully. In addition, the developed risk-related sentiment should be combined with finance-specific sentiment to achieve a more accurate prediction of financial risks. Interestingly, risk-related sentiment was not reflected in investors' expectations expressed using the market to book ratio. In fact, any risk-related communication seems to be perceived negatively by investors, regardless of the tone of the communication. Given these findings, it is tempting to speculate that investors perceive risk-related information without a deeper understanding of the risk management process. This finding also provides support for the prospect theory (Kahneman \& Tversky, 2013), suggesting that investors are risk-averse and not perfectly rational agents.

To sum up, we believe that our findings enhance our understanding of the role of risk-related managerial communication in empirical finance. To the best of our knowledge, this is the first study that covers this important perspective of managerial communication. We foresee that this research will serve as a base for future studies on the prediction of financial risks, such as bankruptcy prediction and credit risk prediction. Predicting stock returns and their volatility seems to be another interesting avenue of future research. One of the limitations of the present study is that word context of the risk-related words was not considered. Therefore, we recommend utilising word embeddings to further modify the proposed word lists. Experts or machine learning methods can also assign weights to the words in the lists to obtain a more precise evaluation of risk-related sentiment.

\section{Acknowledgements}

This article was supported by the scientific research project of the Czech Sciences Foundation Grant No. 19-15498S. 


\section{References}

Altman, E. I. (1968). Financial ratios, discriminant analysis and the prediction of corporate bankruptcy. The Journal of Finance, 23(4), 589-609. https://doi.org/10.1111/j.1540-6261.1968.tb00843.x

Altman, E. I., Iwanicz-Drozdowska, M., Laitinen, E. K., \& Suvas, A. (2017). Financial distress prediction in an international context: A review and empirical analysis of Altman's Z-score model. Journal of International Financial Management \& Accounting, 28(2), 131-171. https://doi.org/10.1111/jifm.12053

Anton, S. G., \& Nucu, A. E. A. (2019). Firm value and corporate cash holdings. Empirical evidence from the Polish listed firms. E\&M Economics and Management, 22(3), 121-134. https://doi.org/10.15240/tul/001/2019-3-008

Arora, M. P., \& Lodhia, S. (2016). The BP Gulf of Mexico oil spill: Exploring the link between social and environmental disclosures and reputation risk management. Journal of Cleaner Production, 140(Part 3), 1287-1297. https://doi.org/10.1016/j.jclepro.2016.10.027

Bodnaruk, A., Loughran, T., \& McDonald, B. (2015). Using 10-k text to gauge financial constraints. Journal of Financial and Quantitative Analysis, 50(4), 623-646. https://doi.org/10.1017/S0022109015000411

Bunget, O. C., Blidisel, R. G., Feleaga, L., \& Popa, I. E. (2014). Empirical study of intangible assets in Romanian municipalities. E\&M Economics and Management, 17(3), 136-151. https://doi.org/10.15240/tul/001/2014-3-011

Bužinskienè, R. (2017). Determination of the value of intangible assets in the companies of Lithuania. Economics and Culture, 14(2), 55-68. https://doi.org/10.1515/jec-2017-0018

Cai, L., \& He, C. (2014). Corporate environmental responsibility and equity prices. Journal of Business Ethics, 125(4), 617-635. https://doi.org/10.1007/s10551-013-1935-4

Cecchini, M., Aytug, H., Koehler, G. J., \& Pathak, P. (2010). Making words work: Using financial text as a predictor of financial events. Decision Support Systems, 50(1), 164-175.

https://doi.org/10.1016/j.dss.2010.07.012

Chang, Y., Benson, K., \& Faff, R. (2017). Are excess cash holdings more valuable to firms in times of crisis? Financial constraints and governance matters. Pacific-Basin Finance Journal, 45, 157-173. https://doi.org/10.1016/j.pacfin.2016.05.007

Chen, P. H., Ong, C. F., \& Hsu, S. C. (2017). Understanding the relationships between environmental management practices and financial performances of multinational construction firms. Journal of Cleaner Production, 139, 750-760. https://doi.org/10.1016/j.jclepro.2016.08.109

Chen, W., Niebel, T., \& Saam, M. (2016). Are intangibles more productive in ICT-intensive industries? Evidence from EU countries. Telecommunications Policy, 40(5), 471-484. https://doi.org/10.1016/j.telpol.2015.09.010

Clarkson, P. M., Fang, X., Li, Y., \& Richardson, G. (2013). The relevance of environmental disclosures: Are such disclosures incrementally informative? Journal of Accounting and Public Policy, 32(5), 410-431. https://doi.org/10.1016/j.jaccpubpol.2013.06.008

Clausen, S., \& Hirth, S. (2016). Measuring the value of intangibles. Journal of Corporate Finance, 40, 110-127. https://doi.org/10.1016/j.jcorpfin.2016.07.012

Cormier, D., \& Magnan, M., (2015). The economic relevance of environmental disclosure and its impact on corporate legitimacy: An empirical investigation. Business Strategy and the Environment, 24(6), 431-450. https://doi.org/10.1002/bse.1829

Cosmulese, C. G., Socoliuc, M., Ciubotariu, M. S., Mihaila, S., \& Grosu, V. (2019). An empirical analysis of stakeholders' expectations and integrated reporting quality. Economic Research-Ekonomska Istraživanja, 32(1), 3963-3986. https://doi.org/10.1080/1331677X.2019.1680303 
Deaconu, A., Crisan, S., \& Buiga, A. (2016). Value allocation - Contribution and risk to the reliability of financial reporting. E\&M Economics and Management, 19(2), 105-119. https://doi.org/10.15240/tul/001/2016-2-007

DellaVigna, S., \& Pollet, J. (2009). Investor inattention and Friday earnings announcements. The Journal of Finance, 64(2), 709-749. https://doi.org/10.1111/j.1540-6261.2009.01447.x

Džunić, M., \& Golubović, N. (2018). Perceived corruption in business environment: Exploring the underlying causes. E\&M Economics and Management, 21(4), 48-64.

https://doi.org/10.15240/tul/001/2018-4-004

Eidelwein, F., Collatto, D., Rodrigues, L., Lacerda, D., \& Piran, F. (2018). Internalization of environmental externalities: Development of a method for elaborating the statement of economic and environmental results. Journal of Cleaner Production, 170, 1316-1327. https://doi.org/10.1016/j.jclepro.2017.09.208

Fama, E. F., \& French, K. R. (2000). Forecasting profitability and earnings. The Journal of Business, 73(2), 161-175. https://doi.org/10.1086/209638

Fazzari, S. M., \& Variato, A. M. (2015). Asymmetric information and Keynesian theories of investment. Journal of Post Keynesian Economics, 16(3), 351-370. https://doi.org/10.1080/01603477.1994.11489990

Fejes, J. (2018). The role of intangible assets in the banking value creation process [ $\mathrm{PhD}$ Thesis]. Corvinus University Budapest. http://phd.lib.uni-corvinus.hu/995/18/Fejes_Jozsef_ten.pdf

Flammer, C. (2013). Corporate social responsibility and shareholder reaction: The environmental awareness of investors. Academy of Management Journal, 56(3), 758-781. https://doi.org/10.5465/amj.2011.0744

Frank, M. Z., \& Goyal, V. K. (2009). Capital structure decisions: which factors are reliably important? Financial Management, 38(1), 1-37. https://doi.org/10.1111/j.1755-053X.2009.01026.x

Fuente, J. A., Garcia-Sanchez, I. M., \& Lozano, M. B. (2016). The role of the board of directors in the adoption of GRI guidelines for the disclosure of CSR information. Journal of Cleaner Production, 141, 737-750. https://doi.org/10.1016/j.jclepro.2016.09.155

Gastineau, G. L., \& Kritzman, M. P. (1999). Dictionary of financial risk management (Vol. 52). John Wiley \& Sons.

Ghosh, C. A. (1993). Regret-theoretic explanation of corporate dividend policy. Journal of Business Finance and Accounting, 20(4), 559-573. https://doi.org/10.1111/j.1468-5957.1993.tb00274.x

Goel, S., \& Uzuner, O. (2016). Do sentiments matter in fraud detection? Estimating semantic orientation of annual reports. Intelligent Systems in Accounting, Finance and Management, 23(3), 215-239. https://doi.org/10.1002/isaf.1392

Gray, G. L., \& Debreceny, R. S. (2014). A taxonomy to guide research on the application of data mining to fraud detection in financial statement audits. International Journal of Accounting Information Systems, 15(4), 357-380. https://doi.org/10.1016/j.accinf.2014.05.006

Greco, M., Cricelli, L., \& Grimaldi, M. (2013). A strategic management framework of tangible and intangible assets. European Management Journal, 31(1), 55-66. https://doi.org/10.1016/j.emj.2012.10.005

Groth, S. S., \& Muntermann, J. (2011). An intraday market risk management approach based on textual analysis. Decision Support Systems, 50(4), 680-691. https://doi.org/10.1016/j.dss.2010.08.019

Guenster, N., Bauer, R., Derwall, J., \& Koedijk, K. (2011). The economic value of corporate eco- efficiency. European Financial Management, 17(4), 679-704. https://doi.org/10.1111/j.1468-036X.2009.00532.x

Haimes, Y. Y. (2009). On the complex definition of risk: A systems-based approach. Risk Analysis, 29(12), 1647-1654. https://doi.org/10.1111/j.1539-6924.2009.01310.x 
Hajek, P. (2018). Combining bag-of-words and sentiment features of annual reports to predict abnormal stock returns. Neural Computing and Applications, 29(7), 343-358. https://doi.org/10.1007/s00521-017-3194-2

Hajek, P., \& Henriques, R. (2017). Mining corporate annual reports for intelligent detection of financial statement fraud - A comparative study of machine learning methods. Knowledge-Based Systems, 128, 139-152. https://doi.org/10.1016/j.knosys.2017.05.001

Hajek, P., Olej, V., \& Myskova, R. (2014). Forecasting corporate financial performance using sentiment in annual reports for stakeholders' decision-making. Technological and Economic Development of Economy, 20(4), 721-738. https://doi.org/10.3846/20294913.2014.979456

Henry, E., \& Leone, A. J. (2016). Measuring qualitative information in capital markets research: Comparison of alternative methodologies to measure disclosure tone. The Accounting Review, 91(1), 153-178. https://doi.org/10.2308/accr-51161

Huang, X., Teoh, S. H., \& Zhang, Y. (2014). Tone management. The Accounting Review, 89(3), 10831113. https://doi.org/10.2308/accr-50684

Jordão, R. V. D., \& Almeida, V. R. D. (2017). Performance measurement, intellectual capital and financial sustainability. Journal of Intellectual Capital, 18(3), 643-666. https://doi.org/10.1108/JIC-11-2016-0115

Kahneman, D., \& Tversky, A. (2013). Prospect theory: An analysis of decision under risk. In Handbook of the fundamentals of financial decision making (Part I, pp. 99-127). World Scientific. https://doi.org/10.1142/9789814417358_0006

Kearney, C., \& Liu, S. (2014). Textual sentiment in finance: A survey of methods and models. International Review of Financial Analysis, 33, 171-185. https://doi.org/10.1016/j.irfa.2014.02.006

Kerzner, H. (2009). Project management: A systems approach to planning, scheduling, and controlling. John Wiley.

Kubenka, M., \& Myskova, R. (2019). Obvious and hidden features of corporate default in bankruptcy models. Journal of Business Economics and Management, 20(2), 368-383. https://doi.org/10.3846/jbem.2019.9612

Kumar, A., Cantor, D. E., Grimm, C. M., \& Hofer, C. (2017). Environmental management rivalry and firm performance. Journal of Strategy and Management, 10(2), 227-247. https://doi.org/10.1108/JSMA-11-2015-0089

Kumar, B. S., \& Ravi, V. (2016). A survey of the applications of text mining in financial domain. Knowledge-Based Systems, 114, 128-147. https://doi.org/10.1016/j.knosys.2016.10.003

Li, J., Feng, Y., Li, G., \& Sun, X. (2020). Tourism companies' risk exposures on text disclosure. Annals of Tourism Research, 84, 102986. https://doi.org/10.1016/j.annals.2020.102986

Liu, X., \& Zhang, C. (2016). Corporate governance, social responsibility information disclosure, and enterprise value in China. Journal of Cleaner Production, 142(Part 2), 1075-1084. https://doi.org/10.1016/j.jclepro.2016.09.102

López-Gracia, J., \& Sogorb-Mira, F. (2015). Financial constraints and cash-cash flow sensitivity. Applied Economics, 47(10), 1037-1049. https://doi.org/10.1080/00036846.2014.987918

Loughran, T., \& McDonald, B. (2011). When is a liability not a liability? Textual analysis, dictionaries, and 10-Ks. The Journal of Finance, 66(1), 35-65. https://doi.org/10.1111/j.1540-6261.2010.01625.x

Loughran, T., \& McDonald, B. (2016). Textual analysis in accounting and finance: A survey. Journal of Accounting Research, 54(4), 1187-1230. https://doi.org/10.1111/1475-679X.12123

Maheshwari, Y., \& Rao, K. T. V. (2017). Determinants of corporate cash holdings. Global Business Review, 18(2), 416-427. https://doi.org/10.1177/0972150916668610 
Manzoor, M. S., Rehman, R., Usman, M. I., \& Ahmad, M. I. (2019). How corporate governance and CSR disclosure affect firm performance? E\&M Economics and Management, 22(3), 20-35. https://doi.org/10.15240/tul/001/2019-3-002

Marc, M., Sprčić, D. M., \& Žagar, M. M. (2018). Is enterprise risk management a value added activity? E\&M Economics and Management, 21(1), 68-84. https://doi.org/10.15240/tul/001/2018-1-005

Marty, T., Vanstone, B., \& Hahn, T. (2020). News media analytics in finance: A survey. Accounting \& Finance, 60(2), 1385-1434. https://doi.org/10.1111/acfi.12466

Mengelkamp, A., Hobert, S., \& Schumann, M. (2015). Corporate credit risk analysis utilizing textual user generated content - A Twitter based feasibility study. In Pacific Asia Conference on Information Systems (PACIS) Proceedings, 236.

Myskova, R., \& Hajek, P. (2016). The effect of managerial sentiment on market-to-book ratio. Transformations in Business \& Economics, 15(2A), 498-513.

Myskova, R., \& Hajek, P. (2017). Comprehensive assessment of firm financial performance using financial ratios and linguistic analysis of annual reports. Journal of International Studies, 10(4), 96-108. https://doi.org/10.14254/2071-8330.2017/10-4/7

Myskova, R., \& Hajek, P. (2018). Sustainability and corporate social responsibility in the text of annual reports - The case of the IT services industry. Sustainability, 10(11), 1-18. https://doi.org/10.3390/su10114119

Osinski, M., Selig, P. M., Matos, F., \& Roman, D. J. (2017). Methods of evaluation of intangible assets and intellectual capital. Journal of Intellectual Capital, 18(3), 470-485. https://doi.org/10.1108/JIC-12-2016-0138

Pejic Bach, M., Krstic, Z., Seljan, S., \& Turulja, L. (2019). Text mining for big data analysis in financial sector: A literature review. Sustainability, 11(5), 1277. https://doi.org/10.3390/su11051277

Peng, Y., Wang, G., Kou, G., \& Shi, Y. (2011). An empirical study of classification algorithm evaluation for financial risk prediction. Applied Soft Computing, 11(2), 2906-2915.

https://doi.org/10.1016/j.asoc.2010.11.028

Pröllochs, N., \& Feuerriegel, S. (2020). Business analytics for strategic management: Identifying and assessing corporate challenges via topic modeling. Information \& Management, 57(1), 103070. https://doi.org/10.1016/j.im.2018.05.003

Salameh, A., \& Bashir, H. (2013). Intangible assets and stock price of Jordanian companies: An empirical analysis. European Journal of Business and Social Sciences, 2(9), 153-165. https://doi.org/10.5430/afr.v5n2p154

Sejkora, F., \& Duspiva, P. (2015). The position of management of Czech join-stock companies on dividend policy. E\&M Economics and Management, 18(2), 73-88.

https://doi.org/10.15240/tul/001/2015-2-006

Short, J. C., Broberg, J. C., Cogliser, C. C., \& Brigham, K. H. (2010). Construct validation using computer-aided text analysis (CATA) an illustration using entrepreneurial orientation. Organizational Research Methods, 13(2), 320-347. https://doi.org/10.1177/1094428109335949

Smales, L. A. (2016). News sentiment and bank credit risk. Journal of Empirical Finance, 38(Part A), 37-61. https://doi.org/10.1016/j.jempfin.2016.05.002

Smalt, S. W., \& McComb, J. M. (2016). Accounting for internally generated intangible assets. International Journal of Accounting and Taxation, 4(1), 1-15. https://doi.org/10.15640/ijat.v4n1a1

Song, H., Zhao, C., \& Zeng, J. (2017). Can environmental management improve financial performance: An empirical study of A-shares listed companies in China. Journal of Cleaner Production, 141, 1051-1056. https://doi.org/10.1016/j.jclepro.2016.09.105 
Stulz, R. (2013). How companies can use hedging to create shareholder value. Journal of Applied Corporate Finance, 25(4), 21-29. https://doi.org/10.1111/jacf.12038

Sulub, S. A. (2014). Testing the predictive power of Altman's revised Z' model: The case of 10 multinational companies. Research Journal of Finance and Accounting, 5(21), 174-184.

Tong, Z. (2014). Deviations from optimal corporate cash holdings and the valuation from a shareholder's perspective. Applied Economics, 46(30), 3695-3707.

https://doi.org/10.1080/00036846.2014.939374

Tsai, F. T., Lu, H. M., \& Hung, M. W. (2016). The impact of news articles and corporate disclosure on credit risk valuation. Journal of Banking \& Finance, 68, 100-116. https://doi.org/10.1016/j.jbankfin.2016.03.018

Tsai, M. F., \& Wang, Ch. J. (2017). On the risk prediction and analysis of soft information in finance reports. European Journal of Operational Research, 257(1), 243-250. https://doi.org/10.1016/j.ejor.2016.06.069

U.S. Securities and Exchange Commission. (2019). Filings \& forms - EDGAR system. https://ww.sec. gov/edgar.shtml

Van Dalen, A., De Vreese, C. H., \& Albaek, E. (2017). Mediated uncertainty: The negative impact of uncertainty in economic news on consumer confidence. Public Opinion Quarterly, 81(1), 111-130. https://doi.org/10.1093/poq/nfw039

Vojinović, Ž., Milutinović, S., \& Leković, B. (2020). Micro-specific profitability factors of the Serbian insurance industry: A panel data estimation. E\&M Economics and Management, 23(1), 135-155. https://doi.org/10.15240/tul/001/2020-1-010

Walls, J. L., Berrone, P., \& Phan, P. H. (2012). Corporate governance and environmental performance: Is there really a link? Strategic Management Journal, 33(8), 885-913. https://doi.org/10.1002/smj.1952

Yang, R., Yu, Y., Liu, M., \& Wu, K. (2018). Corporate risk disclosure and audit fee: A text mining approach. European Accounting Review, 27(3), 583-594. https://doi.org/10.1080/09638180.2017.1329660 


\section{APPENDIX}

\section{A: Positive risk-related word list}

Acceptable risk, acceptance of residual risk, accountability, accounts receivable insurance, act of god, actual cash value, actuary, additional insured, admitted company, aggregate limit, allrisk insurance, application of risk, apportionment of risk, appraisal of risk, audit committee, avoid risk, blanket insurance, blanket position bond, business as usual, business continuity management, business continuity plan, business change manager, business impact analysis, case reserves, casualty insurance, CCA, ceding insurance pool, certificate of insurance, claim to insurance indemnity, close call, collision insurance, common cause failure, communicate risk, communication plan, consequences analysis, consequences function, contingencies, contingency planning, contingency reserve, continual checking, contract of adhesion, controllable risk, convergent risk management, corporate governance, corporate social responsibility, cost of consequences, counter-measure, cover a risk, covered risk, CRAMM, credibility, credibility threshold, crisis management, CSR, current state of risk, decision tree, decreasing risk, description of risk events, disability management, disaster management, disaster recovery, displaying risk, earthquake insurance, eliminate risk, emergency management, enhancement, enterprise risk management, environmental quality indicator, errors and omissions insurance, ETA, event tree analysis, expected value, exploitation, failure criteria, failure mode and effect analysis, failure modes, effects and criticality analysis, failure reason identification, fault tree analysis, FL-W, FMEA, FMECA, FTA, fuzzy set and verbal verdict method, gateway review, hazard identification, hazard insurance, hazard management, hazard operability study, hazard operation process, HAZOP, holistic risk management, horizon scanning, HRA, human reliability analysis, IAEA-TECDOC-727, indemnity, informed decision to take a particular risk, initial risk identification, insurance, insured risk, issue actionee, key risk indicators, KRI, level of risk, liability insurance, likelihood, loss reserve, management of risk, mitigation, nature of risk, near hit, negligible risk, normalization of deviance, occasional risk, on-going risk identification, opportunity, performance criteria, PHA, potential consequences, predictable risk, preliminary hazard analysis, prioritizing risk, probabilistic safety assessment, probabilities, process quantitative risk analysis, PSA, public relations, pursue risk, QRA, qualitative risk, quality and process risk, quality assurance, quantitative risk, range for consequence, ranking risk, reduction in hazard, referential risk level, reinsurance, relative ranking, relieve a risk, renewal, replacement cost insurance, rescue management, residual risk, resilience, retain risk, reviewing risk, risk absorption, risk acceptance, risk actionee, risk analysis, risk appetite, risk approval, risk assessment, risk attitude, risk aversion, risk avoidance, risk categorization, risk cause analysis, risk committee, risk communication, risk control, risk cover, risk criteria, risk definition, risk description, risk distribution, risk elimination, risk estimation, risk evaluation, risk frequency, risk identification, risk limit, risk magnitude, risk management, risk management audit, risk management framework, risk management plan, risk management policy, risk manager, risk map, risk matrix, risk mitigation, risk monitoring, risk of timing, risk owner, risk parameters, risk perception, risk potential assessment, risk premium, risk prevention, risk probability, risk profile, risk questionnaire, risk rating, risk reduction, risk register, risk reporting, risk response, risk retention, 
risk review, risk review, risk severity, risk sharing, risk strategy, risk tolerance, risk transfer, risk treatment, risk urgency assessment, riskiness, RPA, salvage, security check, semiquantitative risk analysis, senior responsible owner, settlement, shift the risk, social licence to operate, spread a risk, success criteria, supervising, supply chain risk, surety, surplus, threat level, tolerable risk, vulnerability group, warranty, what if, zurich hazard analysis.

\section{B: Negative risk-related word list}

Absolute liability, accident, accrued risk, accumulated risk, additional risk, adverse selection, aggregate amount clause, allocated loss adjustment expense, AOE, arising out of the course of employment, assume the risk, assumption of risk, bear the risk, bodily injury, budget risk, burglary, business interruption, business necessity, business risk, calculated risk, catastrophe, cause of action, COE, collision, competition risk, complementary risk, compliance risk, consequential damage, consequential loss, credit risk, crisis, critical point, cultural risk, currency risk, damage, danger, decline, default risk, defendant, degree of threat, depression, disability, disaster, dis-benefit, downside risk, ecological risk, economic risk, emergency, enhanced risk, entrepreneurship risk, environmental risk, ergonomic risk, events outside our control, external risk, extraneous risk, failure, financial loss, financial risk, fraud, hazard, hazardous working condition, health risk, high flyers, illness caused, imminence, incident, incident report, increased hazard, increasing frequency of risk, increasing risk, incur a risk, incurred loss, information risk, information security risk, infrastructure risk, inherent risk, injury caused, inland risk, insurance risk, interest rate risk, internal risk, intolerable risk, intrinsic risk, jeopardy, legal risk, leverage, liquidation risk, market risk, maturity gap exposure, mishap, modifiable risk, natural disaster risk, natural risk, near miss, negligence, nonmarket risk, non-systematic risk, objective risk, occupational accident, occurring in the course of employment, operational risk, outside risk, outward risk, overall risk, peak risk, peril, political risk, potential risk, primary risk, programmatic risk, programme risk, project risk, proliferate risk, reputational risk, resource risk, risk aggregation, risk assets, risk capital, risk cause, risk effect, risk event, risk exposure, risk financing, risk for own account, risk of additional costs, risk of damage, risk of extra costs, risk of lost revenue, risk of selection, risk sources, robbery, root causes of loss, run a risk, run the risk, secondary risk, sectoral risk, severity of risk, social risk, source of danger, specific risk, storage risk, strategic risk, subjective risk, subpoena, subscribed risk, supplementary risk, supplier risk, susceptibility, systematic risk, tactical risk, take over risk, take the risk, technical environment risk, technological risk, threat level, tortfeasor, trade risk, turn away from risk, typical risk, ultimate losses, unacceptable risk, unbearable risk, uncertainties, underinsurance, undesirable event, uninsurable risk, unique risk, unpredictable risk, unsafe acts, venture, venture capital, vulnerability, world crisis. 